\title{
Pemodelan Profile Greenhouse Berbasis Neural Network
}

\author{
Muhammad Rizky, Iim Fatimah, dan Melania Suweni Muntini \\ Departemen Fisika, Fakultas Matematika dan Ilmu Pengetahuan Alam, Institut Teknologi Sepuluh Nopember (ITS) \\ e-mail:melania@physics.its.ac.id
}

\begin{abstract}
Abstrak-Pemodelan profile greenhouse merupakan salah satu hal penting untuk memaksimalkan pertumbuhan tanaman yang ditanam di dalam greenhouse. Sebelum dimodelkan, dibandingkan ketika greenhouse dengan sistem otomasi dalam keadaan mati dan ketika greenhouse dengan sistem otomasi dalam keadaan hidup. Dengan diterapkan sistem otomasi dapat meningkatkan kualitas greenhouse dengan cara menurunkan suhu dan meningkatkan kelembaban. Semakin baik kualitas greenhouse maka semakin baik pertumbuhan tanaman dalam greenhouse. Pemodelan dalam penelitian ini digunakan model neural network tipe back-propagation. Profile greenhouse meliputi suhu udara, kelembaban udara, suhu tanah dan kelembaban tanah. Hasilnya ialah profil terbaik dari greenhouse adalah pada suhu udara pukul 16.00 - 07.00, kelembaban udara mencapai 98\%, suhu tanah pukul 18.00 - 08.00 dan kelembaban tanah mencapai $98 \%$ serta hasil pemodelan mendekati data pengukuran dengan nilai kesalahan mencapai $1 \%$.
\end{abstract}

Kata Kunci-Greenhouse, Suhu, Kelembaban, Neural Network.

\section{PENDAHULUAN}

$I^{1}$ NDONESIA merupakan negara di daerah yang beriklim tropis. Ini yang mengakibatkan Indonesia mempunyai dua musim yaitu musim hujan dan musim kemarau. Dua musim ini sangat mempengaruhi proses bercocok tanam. Ada pengaruh baik ada pula pengaruh buruk dari perubahan musim ini. Padahal proses bercocok tanam harus selalu berlangsung untuk memenuhi permintaan pasar akan sayur-sayuran. Pengaruh buruk dari perubahan musim akan menjadi permasalahan proses bercocok tanam. Untuk mengatasi permasalahan ini dibutuhkan suatu tempat budidaya tanaman yaitu greenhouse. Solusi yang dapat diterapkan dalam greenhouse salah satunya sistem otomasi yang fungsinya untuk mengatur suhu dan kelembaban udara serta tanah berdasarkan kebutuhan tanaman.

Greenhouse didesain untuk dijadikan sebuah tempat yang nyaman untuk tanaman bisa tumbuh sepanjang tahun. Hal ini dapat meningkatkan kondisi pertumbuhan tanaman dan melindungi tanaman dari kondisi lingkungan yang tak menentu seperti hujan deras, angin kencang dan suhu yaang ekstrim di musim hujan dan musim panas [1]. Peralatan yang digunakan untuk menganalisa perilaku termal dari greenhouse adalah model kelembaban dan suhu udara untuk pembangunan dan sistem evaluasi. Peralatan ini merupakan desain yang dirancang oleh sumber acuan [2].

Variabel iklim yang utama di dalam sebuah greenhouse yang dapat dikendalikan diantaranya adalah suhu, kelembaban, konsentrasi $\mathrm{CO}_{2}$ dan intensitas cahaya yang dibutuhkan oleh tanaman [3]. Suhu dan kelembaban adalah parameter yang paling diperhatikan di penelitian ini. Kelembaban adalah parameter operasional yang sangat kritis [4], [5], dan [6]. Pembentukan profil kelembaban yang mengandung oksigen sangat berpotensi mendukung kondisi greenhouse. Evaluasi kelembaban selama pembangunan greenhouse sangat membantu identifikasi tingkat kelembaban [6].

Suhu dan kelembaban dalam greenhouse akan dimodelkan dengan digunakan basis neural network. Neural network adalah sebuah kode yang sederhana. Elemen-elemen pengolahan yang sangat saling berhubungan (neuron) dan itu sebagai algoritma komputasi yang memproses data dengan respon yang dinamis dan hubungannya ke data keluaran [7][8]. Neural Network terinspirasi dari sistem kerja saraf seperti proses pengolahan informasi dalam otak. Neural Network terdiri dari neuron-neuron atau elemen-elemen yang bekerja sama untuk memecahkan masalah atau sekumpulan data tertentu [9]. Neural Network telah berhasil dalam berbagai aplikasi. Ada tiga model dari Neural Network yaitu perangkat sinapsis sebagai penghubung, penambah dan fungsi transfer sebagai aktivasi [10]-[11].

Neural network ada beberapa tipe, untuk penelitian ini dipilih tipe back-propagation. Back-propagation adalah salah satu tipe yang terkontrol digunakan pola penyesuaian untuk didapatkan nilai kesalahan yang paling kecil antara data pengukuran dan hasil pemodelan [12]. Konstruksi jaringan back-propagation tidak mempunyai hubungan umpan balik tetapi error dipropagasikan selama proses training. Pada backpropagation digunakan error dengan dihitung least mean. Algoritma ini termasuk algoritma supervised learning [13]. Semakin kecilnya selisih anatara nilai target dan output jaringan ini ditandakan nilai bobot sambungan pada jaringan menuju nilai tertentu, hal ini dihasilkan pada proses training [14].

Objek yang dipilih dalam penelitian ini yaitu greenhouse yang ditanami tanaman tomat. Dalam penentuan profil terbaik green house dan mendapatkan regresi pemodelan profil terbaik digunakan basis neural network.

\section{METODOLOGI}

\section{A. Alat dan Bahan}

Alat yang digunakan pada penelitian ini adalah software MatLab dengan metode Neural Network. Bahan yang dijadikan pemodelan dalam penelitian ini adalah suhu dan 
kelembaban udara serta tanah di dalam greenhouse. Greenhouse yang digunakan sebagai penelitian adalah greenhouse untuk tanaman tomat.

\section{B. Langkah Kerja}

Alur tahapan kerja dalam penelitian ini dapat dilihat pada Gambar 1 sebagai berikut:

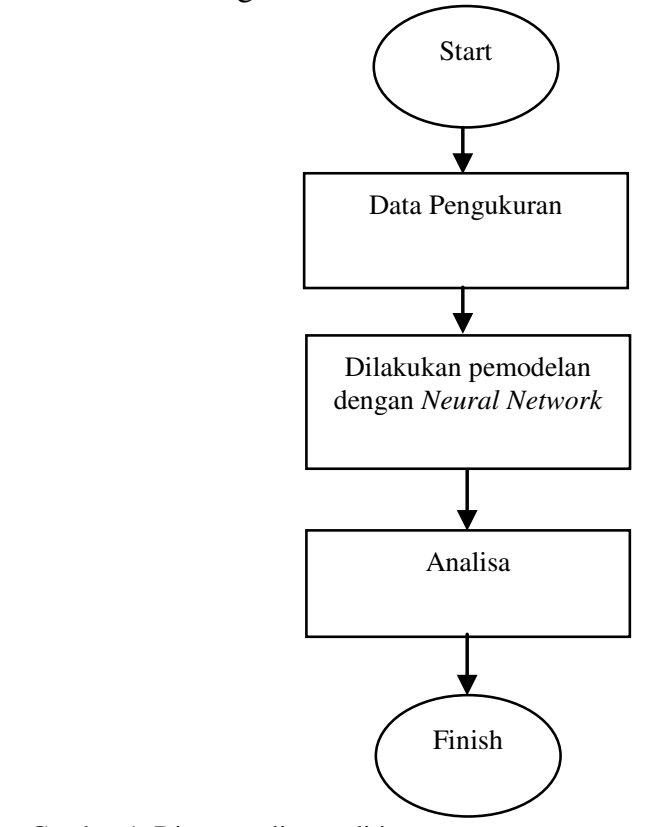

Gambar 1. Diagram alir penelitian.

Pengukuran dilakukan untuk nilai input pada basis neural network. Pengukuran meliputi suhu dan kelembaban udara serta tanah, 24 jam pertama dengan sistem automasi dalam keadaan mati kemudian 24 jam berikutnya dengan sistem otomasi dalam keadaan hidup dilakukan secara berturut-turut selama 14 x 24 jam. Sistem otomasi dalam greenhouse terdiri dari penyiraman tanaman dengan air melalui 12 sprayer kabut dan 4 kipas angin untuk distribusi suhu dan kelembaban. Pengukuran suhu dan kelembaban udara digunakan sensor DHT11. Pengukuran suhu tanah digunakan sensor DS18B20. Pengukuran kelembaban tanah digunakan sensor soil moisture.

Setelah didapatkan data pengukuran dilakukan pemodelan dengan basis neural network tipe back-propagation. Pada back-propagation ada proses yang dinamakan feed-forward untuk didapatkan nilai output pada layer-layer yang digunakan. Pada proses itu dimanfaat nilai bobot $\mathrm{w}$ dan faktor bias pada data input. Pada basis neural network tipe backpropagation dijalankan proses trial dan error untuk ditentukan komposisi terbaik meliputi banyaknya neuron dan layer yang digunakan.

\section{ANALISA DATA DAN PEMBAHASAN}

\section{A. Suhu Udara}

Suhu udara adalah salah satu parameter yang paling berpengaruh pada pertumbuhan tanaman dalam greenhouse. Didapatkan data berupa suhu udara di 12 titik dalam greenhouse yang ditunjukkan oleh Gambar 2 sebagai berikut:

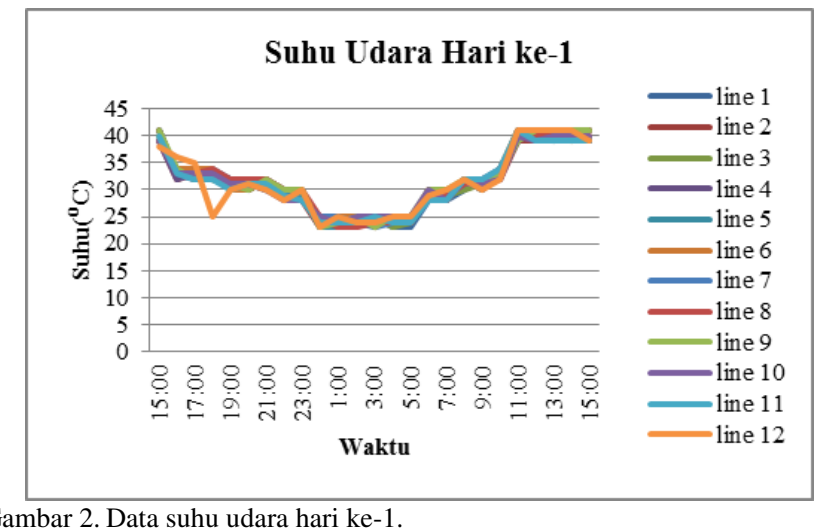

Pada hari ke-1 ini kondisi greenhouse dengan sistem otomasi dalam keadaan mati. Dengan ini dapat diketahui profil suhu udara dalam greenhouse sebelum sistem otomasi dinyalakan. Dapat dilihat pada grafik di atas suhu udara dalam greenhouse masih tidak stabil. Tidak stabilnya suhu udara ini dapat memberi efek buruk pada pertumbuhan tanaman dalam greenhouse.

Didapatkan data di hari selanjutnya yaitu suhu udara hari ke-2 dalam greenhouse dengan kondisi sistem otomasi dalam keadaan hidup yang ditunjukkan oleh Gambar 3 sebagai berikut:

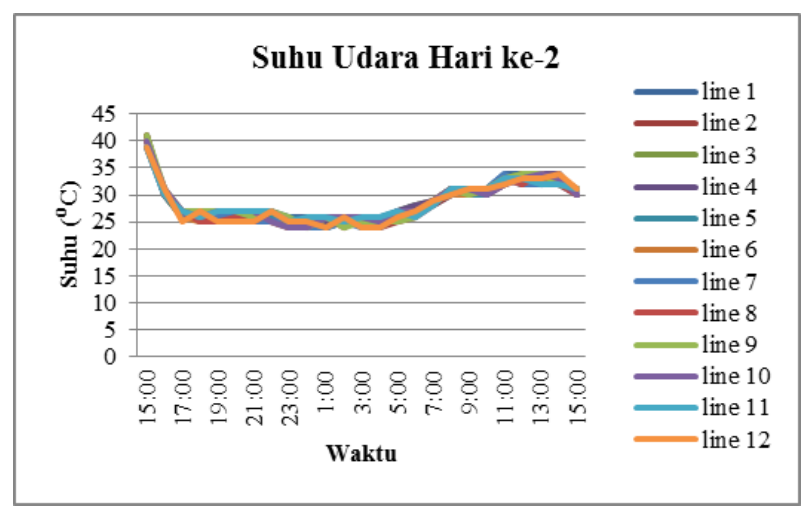

Gambar 3. Data suhu udara hari ke-2.

Data suhu udara pada hari ke-2 dapat dikatakan stabil dan cenderung konstan. Hal ini dikarenakan suhu udara dikontrol oleh sistem otomasi. Suhu udara pukul 15.00 ke pukul 16.00 mengalami penurunan secara drastis dari $40^{\circ} \mathrm{C}$ menjadi $27^{\circ} \mathrm{C}$. Hal ini dikarenakan sistem otomasi baru dinyalakan pukul 15.00. Hasil kerja sistem otomasi dapat dilihat mulai pukul 16.00. Dilihat suhu udara stabil dan cenderung konstan pukul 16.00 sampai pukul 05.00. Sistem otomasi bekerja pukul 16.00 sampai pukul 23.00. Sistem otomasi tidak bekerja mulai pukul 23.00 sampai pukul 05.00 dikarenakan suhu udara memang sudah rendah. Sistem otomasi ini digunakan untuk menurunkan suhu udara ketika pada nilai tinggi. Diturunkan suhu udara dalam greenhouse ditujukan untuk memaksimalkan pertumbuhan tanaman dalam greenhouse. Ketika pukul 05.00 sistem otomasi ini mulai bekerja lagi secara otomatis dikarenakan sinar matahari mulai muncul yang mengakibatkan 
suhu udara meningkat. Tetapi suhu udara tetap meningkat sedikit demi sedikit sampai $34^{\circ} \mathrm{C}$. Hal ini dikarenakan atap greenhouse terbuat dari material paranet jadi suhu udara lingkungan luar sedikit menganggu kinerja sistem otomasi. Atap yang terbuat dari paranet ini mengakibatkan kinerja system otomasi kurang maksimal. Setelah diperoleh data selama 14 hari dan dapat dilihat pola suhu udara dalam greenhouse dilakukan pendekatan secara komputasi dengan model neural network. Didapatkan regresi untuk suhu udara dalam greenhouse sebagai berikut:

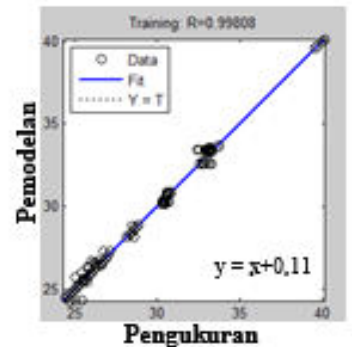

(a)

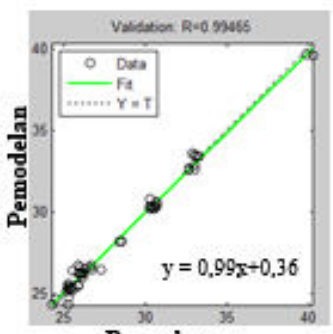

(b)

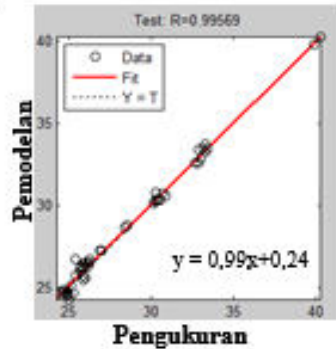

(c)

Gambar 4. Regresi antara pengukuran dan hasil pemodelan suhu udara (a) training, (b) validation, (c) test.

Dari ketiga regresi yang didapatkan, diambil satu regresi yaitu regresi untuk data testing dikarenakan regresi testing adalah regresi yang diperoleh saat pengujian model suhu udara. Berdasarkan regresi testing, model ini dapat menjelaskan variabilitas data sebesar 0,99569 sehingga pada saat pengujian model suhu udara kesesuaian mendekati sempurna. Sedangkan sisanya dijelaskan oleh model lain. Jadi untuk suhu udara dalam greenhouse didapatkan persamaan yaitu

$$
y=0,99 x+0,24
$$

dengan arti setiap pertambahan satu satuan suhu udara akan meningkatkan keluaran sebesar 0,99. Dari Persamaan (1) didapatkan nilai $\mathrm{b}$ positif sehingga menghasilkan regresi dengan hubungan linier positif. Dari persamaan yang didapatkan menunjukkan bahwa hasil pemodelan sudah mendekati data pengukuran. Ini juga menunjukkan bahwa pengukuran data yang telah dilakukan sudah benar.

\section{B. Kelembaban Udara}

Kelembaban udara adalah kandungan uap air yang terdapat dalam udara. Kelembaban udara dibutuhkan oleh tanaman ditujukan untuk agar tanaman tidak mudah kering atau layu. Keringnya tanaman diakibatkan oleh panasnya matahari dan penguapan permukaan tanah dari dalam bumi.

Didapatkan data kelembaban udara di 12 titik dalam greenhouse yang ditunjukkan oleh Gambar 5 sebagai berikut.

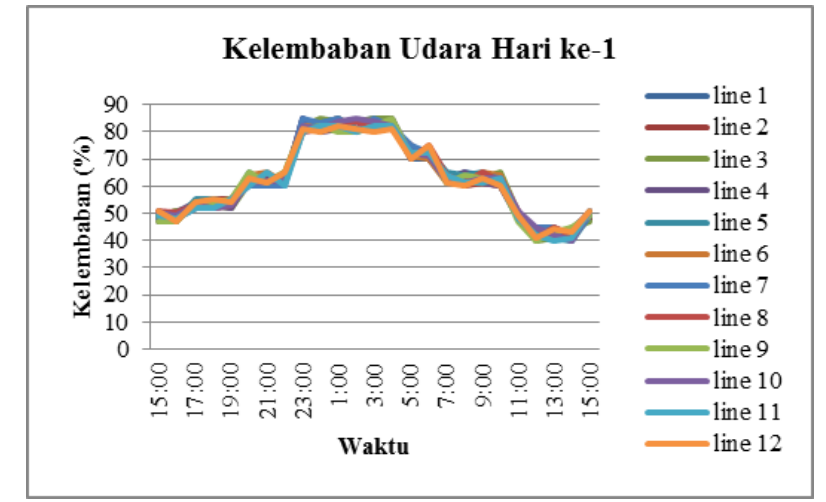

Gambar 5. Data kelembaban udara hari ke-1.

Pengukuran data kelembaban udara juga dimulai pukul 15.00. Pada hari ke- 1 ini kondisi greenhouse dengan sistem otomasi dalam keadaan mati. Dengan keadaan seperti ini, kelembaban udara dalam greenhouse jauh dari yang diharapkan dan yang dibutuhkan tanaman masih kurang mencukupi. Tanaman tomat membutuhkan kelembaban udara mendekati $80 \%$.

Dapat dilihat pada Gambar 5, terjadi peningkatan secara drastis dari pukul 23.00 menuju pukul 00.00. Peningkatan kelembaban udara secara drastis ini sebesar $20 \%$. Ketika pukul 00.00 kelembaban udara sebesar $80 \%$ dan konstan sampai pukul 04.00. Semakin malam hari semakin meningkat kelembaban udara dalam greenhouse. Hal ini disebabkan semakin malam hari semakin rendah suhu udara dan tidak adanya panas matahari. Disini, suhu udara memiliki hubungan dengan kelembaban udara. Semakin rendah suhu udara semakin tinggi kelembaban udara. Pengukuran kelembaban udara di 12 titik dalam greenhouse dilanjutkan pada hari ke- 2 yang ditunjukkan oleh Gambar 6 sebagai berikut:

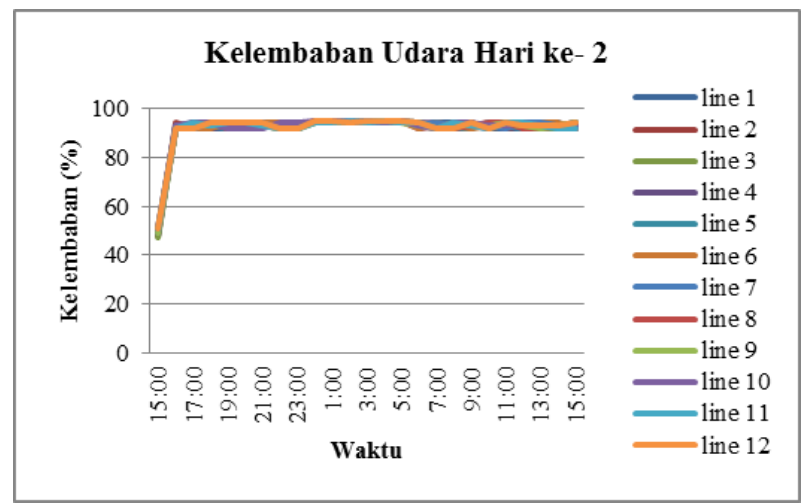

Gambar 6. Data kelembaban udara hari ke-2.

Pengukuran kelembaban udara pada hari ke- 2 dalam greenhouse ini dengan kondisi sistem otomasi dalam keadaan hidup. Berdasarkan data yang didapatkan, pada pukul 15.00 kelembaban udara bernilai $48 \%$ dan mengalami peningkatan secara drastis menjadi $96 \%$ pada pukul 17.00. Hal ini dikarenakan sistem otomasi mulai bekerja pada pukul 15.00. Hasil dari kinerja sistem otomasi dapat dilihat mulai pukul 16.00. Lamanya kinerja sistem otomasi ini untuk meningkatkan kelembaban udara juga diakibatkan oleh atap greenhouse yang terbuat dari material paranet. Sehingga kelembaban udara di luar dan di dalam greenhouse tidak ada 
batas pemisah. Secara tidak langsung kelembaban udara di dalam greenhouse terganggu oleh lingkungan luar greenhouse. Tetapi sistem otomasi ini bisa mempertahankan kelembaban udara diatas $90 \%$ sampai 24 jam. Kelembaban udara dalam greenhouse dengan bantuan sistem otomasi ini bisa dikatakan mencukupi kelembaban udara yang dibutuhkan oleh tanaman tomat. Dikarenakan tanaman tomat membutuhkan kelembaban udara minimal $80 \%$. Dilakukan pendekatan kelembaban udara secara komputasi dengan model neural network yang ditunjukkan oleh Gambar 7 sebagai berikut:

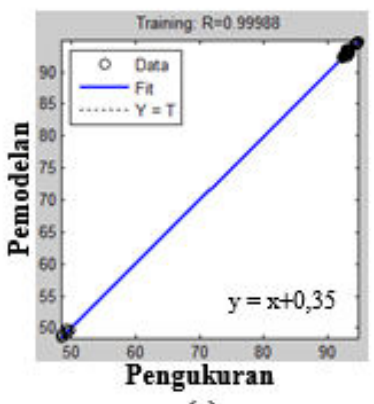

(a)

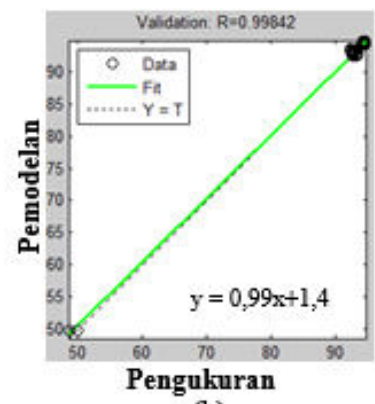

(b)

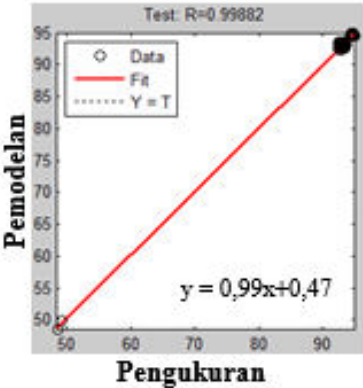

(c)

Gambar 7. Regresi antara pengukuran dan hasil pemodelan kelembaban udara (a) training, (b) validation, (c) test.

Dari ketiga regresi yang didapatkan, diambil satu regresi yaitu regresi untuk data testing dikarenakan regresi testing adalah regresi yang diperoleh saat pengujian model kelembaban udara. Berdasarkan regresi testing, model ini dapat menjelaskan variabilitas data sebesar 0,99882 sehingga pada saat pengujian model kelembaban udara kesesuaian mendekati sempurna. Sedangkan sisanya dijelaskan oleh model lain. Jadi untuk suhu udara dalam greenhouse didapatkan persamaan yaitu

$$
y=0,99 x+0,47
$$

dengan arti setiap pertambahan satu satuan kelembaban udara akan meningkatkan keluaran sebesar 0,99. Dari Persamaan (2) didapatkan nilai $\mathrm{b}$ positif sehingga menghasilkan regresi dengan hubungan linier positif. Dari persamaan yang didapatkan menunjukkan bahwa hasil pemodelan sudah mendekati data pengukuran. Ini juga menunjukkan bahwa pengukuran data yang telah dilakukan sudah benar.

\section{Suhu Tanah}

Suhu tanah lebih rendah daripada suhu udara. Hal ini dikarenakan wujud tanah adalah zat padat. Zat padat memiliki karakter atom satu dengan atom yang lain saling tarik menarik. Tanah juga bermanfaat sebagai tempat resapan air. Jadi tanah lebih dapat mempertahankan suhu rendah daripada udara.
Didapatkan data suhu tanah di 12 titik dalam greenhouse pada hari ke- 1 yang ditunjukkan oleh Gambar 8 sebagai berikut:

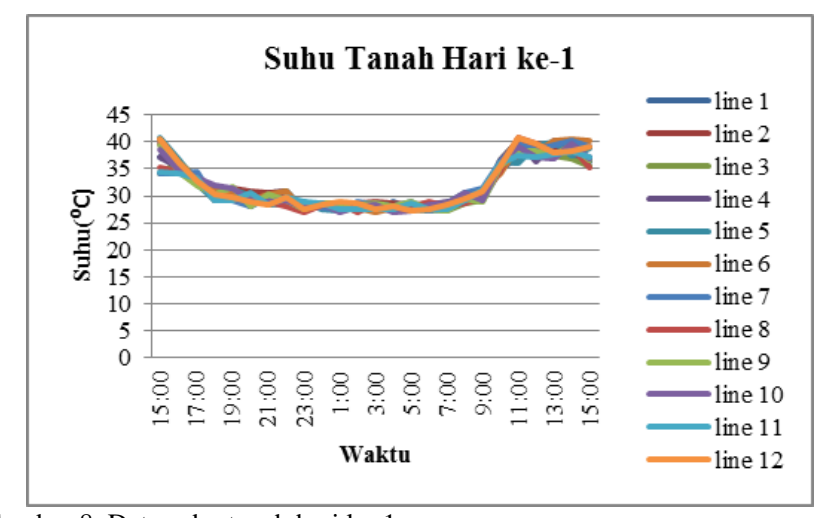

Gambar 8. Data suhu tanah hari ke-1.

Pada hari ke-1 kondisi greenhouse dengan sistem otomasi dalam keadaan mati. Berdasarkan data yang diperoleh, ketika pukul 15.00 suhu tanah berada di antara $34^{\circ} \mathrm{C}$ sampai $41^{\circ} \mathrm{C}$. Semakin malam hari semakin turun suhu tanah. Hal ini dikarenakan tidak ada lagi radiasi panas matahari yang menuju ke permukaan tanah. Pada pukul 17.00 suhu tanah menjadi $33^{\circ} \mathrm{C}$. Suhu tanah turun lagi menjadi $30^{\circ} \mathrm{C}$ pada pukul 19.00 . Turun lagi pada pukul 23.00 suhu tanah menjadi $27^{\circ} \mathrm{C}$ dan tetap konstan sampai pukul 07.00. Suhu tanah mengalami peningkatan pada pukul 09.00 menjadi $30^{\circ} \mathrm{C}$. Suhu tanah mengalami peningkatan secara drastis dari pukul 09.00 menuju pukul 11.00. Peningkatan secara drastis ini dalam rentang $7^{\circ} \mathrm{C}$ sampai $10^{\circ} \mathrm{C}$. Hal ini dikarenakan radiasi panas matahari ke permukaan tanah dimulai pukul 10.00. Suhu tanah tetap konstan sampai pukul 15.00 dikarenakan panas matahari berakhir pada pukul 15.00 .

Pengukuran suhu tanah dilanjutkan di kemudian hari sehingga didapatkan data suhu tanah pada hari ke- 2 yang ditunjukkan oleh Gambar 9 sebagai berikut:

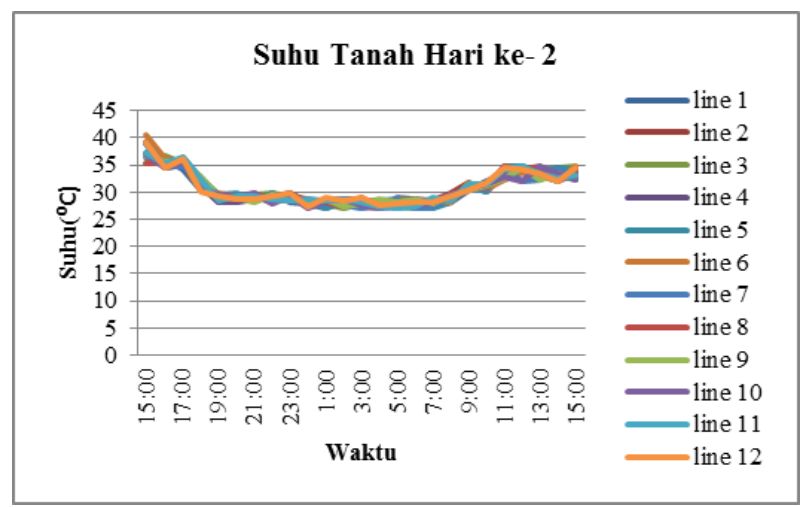

Gambar 9. Data suhu tanah hari ke- 2.

Pada hari ke-2 pengukuran suhu tanah di 12 titik dalam greenhouse dengan sistem otomasi dalam keadaan hidup. Berdasarkan data yang diperoleh, suhu tanah dari pukul 15.00 menuju pukul 16.00 mengalami penurunan yang begitu cepat. Begitu pula yang terjadi pada pukul 17.00 menuju pukul 19.00. Hal ini dikarenakan hasil kinerja dari sistem otomasi yang menurunkan suhu tanah. Dari pukul 19.00 suhu tanah 
tetap konstan sampai pukul 07.00. Suhu tanah mengalami peningkatan secara drastis dari pukul 07.00 menuju pukul 11.00. Hal ini dikarenakan radiasi panas matahari ke permukaan tanah dimulai pukul 08.00. Walaupun sistem otomasi masih dalam keadaan hidup, suhu udara tetap mengalami peningkatan. Hal ini dikarenakan atap greenhouse terbuat dari material paranet. Jadi tidak ada pelindung permukaan tanah dari radiasi panas matahari. Suhu tanah pada pukul 11.00 tetap konstan sampai pukul 15.00. Hal ini dikarenakan panas matahari berakhir pada pukul 15.00. Setelah didapatkan data pengukuran suhu tanah, dilakukan pendekatan secara komputasi dengan model neural network yang ditunjukkan oleh Gambar 4.11 sebagai berikut:

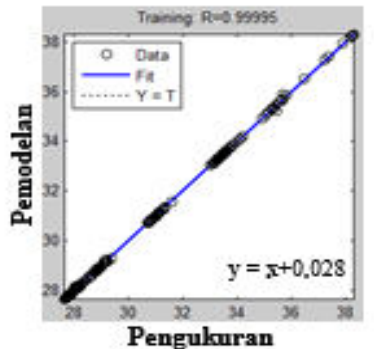

(a)

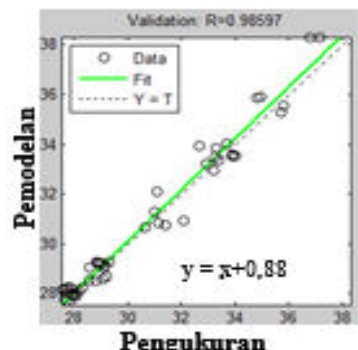

(b)

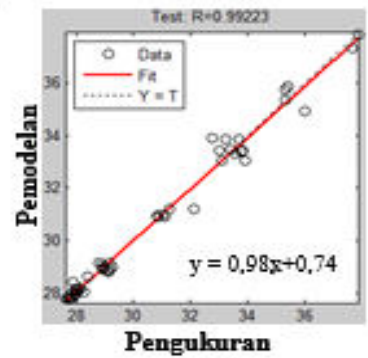

(c)

Gambar 10. Regresi antara pengukuran dan hasil pemodelan suhu tanah (a) training, (b) validation, (c) test.

Dari ketiga regresi yang didapatkan, diambil satu regresi yaitu regresi untuk data testing dikarenakan regresi testing adalah regresi yang diperoleh saat pengujian model suhu tanah. Berdasarkan regresi testing, model ini dapat menjelaskan variabilitas data sebesar 0,99223 sehingga pada saat pengujian model suhu tanah kesesuaian mendekati sempurna. Sedangkan sisanya dijelaskan oleh model lain. Jadi untuk suhu tanah dalam greenhouse didapatkan persamaan yaitu

$$
\mathrm{y}=0,98 \mathrm{x}+0,74
$$

dengan arti setiap pertambahan satu satuan suhu udara akan meningkatkan keluaran sebesar 0,98. Dari Persamaan (3) didapatkan nilai $\mathrm{b}$ positif sehingga menghasilkan regresi dengan hubungan linier positif. Dari persamaan yang didapatkan menunjukkan bahwa hasil pemodelan sudah mendekati data pengukuran. Ini juga menunjukkan bahwa pengukuran data yang telah dilakukan sudah benar.

\section{Kelembaban Tanah}

Kelembaban tanah adalah kandungan air dalam tanah. Kelembaban tanah memiliki nilai yang lebih tinggi daripada kelembaban udara. Hal ini dikarenakan tanah lebih dapat mempertahankan kelembaban daripada udara. Ini juga dikarenakan dari fungsi tanah itu sebagai daerah resapan air. Didapatkan data pengukuran kelembaban tanah di 12 titik ddalam greenhouse pada hari ke- 1 yang ditunjukkan oleh Gambar 11 sebagai berikut:

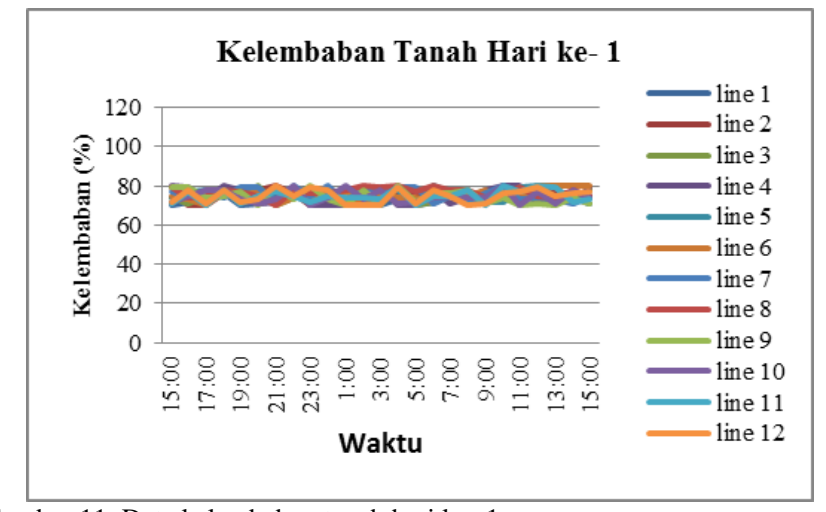

Gambar 11. Data kelembaban tanah hari ke- 1.

Pada hari ke- 1 kondisi greenhouse dengan sistem otomasi dalam keadaan mati. Berdasarkan data yang didapatkan, kelembaban tanah tidak stabil dan cenderung konstan dalam rentang $70 \%$ sampai $80 \%$ selama 24 jam. Hal ini dikarenakan radiasi panas matahari yang menuju ke permukaan tanah. Dan juga dikarenakan atap greenhouse terbuat dari material paranet sehingga tidak ada pelindung permukaan tanah dari radiasi panas matahari.

Pengukuran data kelembaban tanah dilanjutkan di kemudian hari. Data kelembaban tanah pada hari ke- 2 ditunjukkan oleh gambar 12 sebagai berikut:

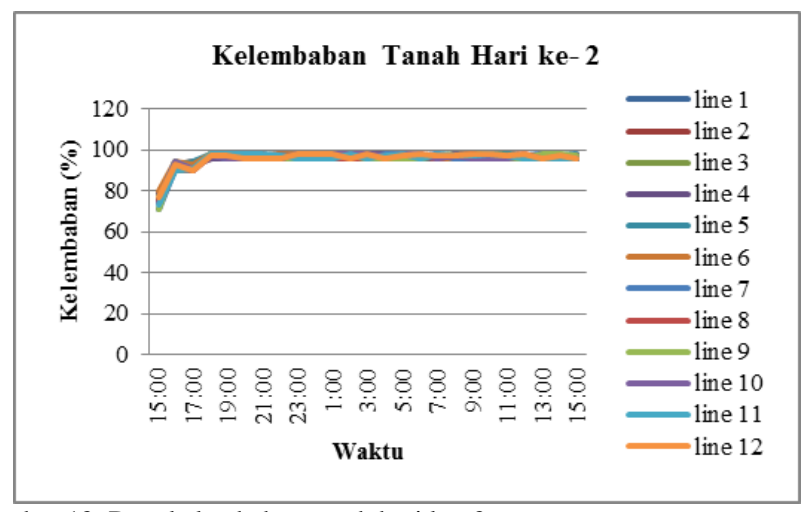

Gambar 12. Data kelembaban tanah hari ke- 2.

Pada hari ke- 2 kondisi greenhouse dengan sistem otomasi dalam keadaan hidup. Berdasarkan data yang didapatkan, Kelembaban tanah bernilai 98\% tetap konstan sampai esok hari. Hal ini dikarenakan sistem otomasi bekerja dengan baik dan sifat dari tanah dapat mengikat kelembaban. Kelembaban sebesar $98 \%$ ini sangat mencukupi kebutuhan tanaman tomat dalam greenhouse. Tanaman tomat membutuhkan kelembaban tanah minimal $80 \%$. Setelah didapatkan data pengukuran kelembaban tanah, dilakukan pendekatan secara komputasi dengan model neural network yang ditunjukkan oleh Gambar 13 sebagai berikut: 


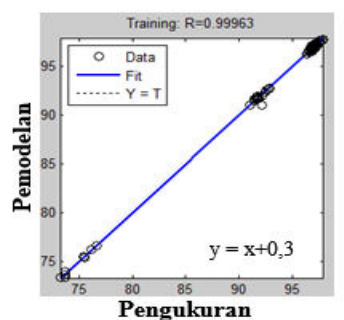

(a)

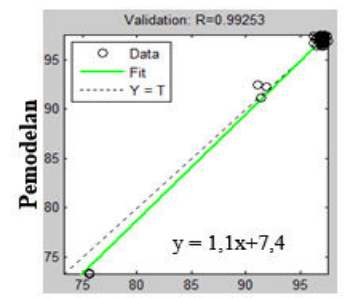

Pengukuran

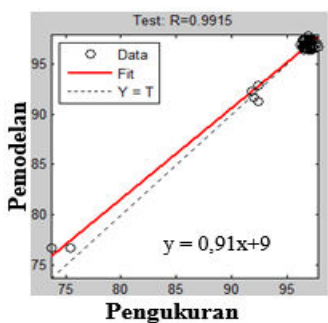

(c)

Gambar 13. Regresi antara pengukuran dan hasil pemodelan kelembaban tanah (a) training, (b) validation, (c) test.

Dari ketiga regresi yang didapatkan, diambil satu regresi yaitu regresi untuk data testing dikarenakan regresi testing adalah regresi yang diperoleh saat pengujian model kelembaban tanah. Berdasarkan regresi testing, model ini dapat menjelaskan variabilitas data sebesar 0,9915 sehingga pada saat pengujian model kelembaban tanah kesesuaian mendekati sempurna. Sedangkan sisanya dijelaskan oleh model lain. Jadi untuk kelembaban tanah dalam greenhouse didapatkan persamaan yaitu:

$$
\mathrm{y}=0,91 \mathrm{x}+9
$$

dengan arti setiap pertambahan satu satuan suhu udara akan meningkatkan keluaran sebesar 0,91. Dari Persamaan (4) didapatkan nilai $\mathrm{b}$ positif sehingga menghasilkan regresi dengan hubungan linier positif. Dari persamaan yang didapatkan menunjukkan bahwa hasil pemodelan sudah mendekati data pengukuran. Ini juga menunjukkan bahwa pengukuran data yang telah dilakukan sudah benar.

\section{KESIMPULAN}

Kesimpulan dari penelitian ini adalah profil terbaik dari greenhouse adalah pada suhu udara pukul 16.00 - 07.00, kelembaban udara mencapai $98 \%$, suhu tanah pukul $18.00-$ 08.00 dan kelembaban tanah mencapai 98\% serta hasil pemodelan mendekati data pengukuran dengan nilai kesalahan mencapai $1 \%$. Saran untuk penelitian kedepannya adalah digunakan greenhouse dengan dinding dan atap yang terbuat dari material yang lebih berkualitas.

\section{DAFTAR PUSTAKA}

[1] A. Ali, K. Ishaque, A. Lashin, and N. Al Arifi, "Modeling of a liquid desiccant dehumidification system for close type greenhouse cultivation," 2016.

[2] Adrianus, "Integrated heat air and moisture modeling andsimulation," Eindhoven University of Technology, 2007.

[3] V. Beveren, P. J. M. Bontsema, J. van Straten, and G. van Henten, "Optimal control of greenhouse climate using minimal energy and grower defined bounds," Appl. Energy, vol. 159, pp. 509-519, 2015.

[4] A. D. Dorado, J. Lafuente, D. Gabriel, and X. Gamisans, "The role of water in the performance of biofilters: parameterization of pressure drop and sorption for common packing materials," J. Hazard. Mater., vol. 180, pp. 693-702, 2010.

[5] L. Chen et al., "Performance evaluation of a wood-chip based biofilter using solid-phase microextraction and gas chromatographyemass spectroscopyeolfactometry," Bioresour. Technol., vol. 99, pp. 77677780, 2008.

[6] G. D. Maia, R. S. Gates, J. L. Taraba, and M. S. Coyne, "Moisture effects on greenhouse gases generation in nitrifying gas-phase compost biofilters," Water Res., vol. 46, pp. 3023-3031, 2012.

[7] K. L. Hsieh and Y. S. Lu, "Model construction and parameter effect for TFT-LCD process based on yield analysis by using ANNs and stepwise regression," Expert Syst. Appl., vol. 34, no. 1, pp. 717-724, 2008.

[8] F. He and C. Ma, "Modeling greenhouse air humidity by means of artificial Neural Network and principal component analysis," Comput. Electron. Agric., vol. 71, pp. S19-S23, 2010.

[9] Anonymous, "No [Online]. Available: www.doc.ic.ac.uk/ nd/surprise_96/journal/vol4/cs11/report.html .

[10]S. Haykin, Neural Networks: A Comprehensive Foundation, 2nd ed. Ontario: Prentice Hall PTR, 1998.

[11]K. Espinoza, D. L. Valera, J. A. Torres, A. López, and F. D. Molina-Aiz, "Combination of image processing and artificial Neural Networks as a novel approach for the identification of Bemisia tabaci and Frankliniella occidentalis on sticky traps in greenhouse agriculture," Comput. Electron. Agric, vol. 127, pp. 495-505, 2016.

[12]F. Suhandi, "Algoritma Back Propagation," 2009.

[13]Anonymous, "No Title." [Online]. Available: www.metodealgoritma.com.

[14]Nurhayati and Fitri, "Penerapan Metode Back Propagation Neural Network pada Pendeteksian Kelainan Otak Ischemic Cerebral Infraction dengan Bahasa Pemrograman Delphi," J. Fis. dan Apl., vol. 6, no. 1, 2010 . 